\title{
Comparison of Physicochemical Quality between Nata De Whey and Nata De Coco
}

Asmaul Khusna ${ }^{1 *}$, Anis Usfah Prastujati ${ }^{1}$, Shinta Setiadevi ${ }^{1}$, Mohamad Ilham Hilal ${ }^{1}$

${ }^{1}$ Study Program of Livestock Product Processing Tecnology, Politeknik Negeri Banyuwangi, Banyuwangi, East Java, Indonesia

DOI: $10.36347 /$ sjavs.2021.v08i04.002

| Received: 12.03.2021 | Accepted: 16.04.2021 | Published: 27.04.2021

*Corresponding author: Asmaul Khusna

Abstract

Original Research Article

The utilization of whey is not only used for food extras but can also be taken other bioactive components. Whey has several bioactive ingredients such as organic acids (lactic acid), active peptides, and proteins that act as antimicrobials, antioxidants, and immune system boosters. Another use of whey cheese is to make whey cheese into fermented products, such as Acetobacter xylinum with functional food products, namely nata de whey. This study used a twofactorial randomized block design (RBD). The first factor is the difference in the source of raw materials, namely coconut water (P0) and whey cheese (P1), and the second factor is the length of fermentation, namely 11 days and 14 days with three replications. The results of the Physical quality (yield and thickness of cellulose) in coconut water raw material (P0) was higher ( $\mathrm{P}>0.05)$ compared to raw material for whey cheese (P1), physical quality of fermentation time treatment and source of raw materials had no interaction, however seen from the average treatment duration of fermentation has an effect, namely $\mathrm{P} 0$ is higher than $\mathrm{P} 1(\mathrm{P}<0.01)$. In terms of chemical qualities such as protein, fat, vitamins were better in nata de whey $(\mathrm{P}<0.01)$, while the crude fiber content was better in coconut water $(\mathrm{P} 0)(\mathrm{P}$ $<0.01)$.

Keywords: Acetobacter Xylinum, Nata de Whey, Whey.

Copyright $(\mathcal{O} 2021$ The Author(s): This is an open-access article distributed under the terms of the Creative Commons Attribution 4.0 International License (CC BY-NC 4.0) which permits unrestricted use, distribution, and reproduction in any medium for non-commercial use provided the original author and source are credited.

\section{INTRODUCTION}

Cheese whey is a byproduct of traditional or modern cheese-making processes. Whey produced in each cheese making reaches about $83 \%$ of the volume of milk used. Whey cheese has not been widely used, even though in cheese whey there is still a high enough protein content so that cheese whey can still be used for processed food products by adding Acetobacter xylinum bacteria, so that it can produce nata the whey [1]. Nata de whey is a type of food fermented by the Acetobacter xylinum bacteria. If Acetobacter xylinum is planted in liquid media containing sugar, it will produce acetic acid and a white layer that floats on the surface of the liquid media [2]. The media for making nata de whey must contain sugar as a carbon source and a $\mathrm{N}$ source as a substrate for the growth of Acetobacter xylinum. Nata de whey starter can be obtained commercially and obtained naturally, for example making Acetobacter xylinum starter seeds from pineapple fruit. Not all of the nutrients contained in the substrate can be fulfilled. Additional nutrients provided in sucrose (carbon) and urea (nitrogen) are required. Nata de whey is very suitable for consumption by people on a low-calorie diet or a diet high in fiber and high in air content. Nata can also function to accelerate the body's metabolic processes because nata de whey fiber in the human body will bind all the remaining elements of the combustion system that are not absorbed by the body, then discharged through the anus in the form of feces or bolus [3].

The manufacture of nata de whey with raw materials from whey cheese is applied to liquid waste in the milk processing industry in Indonesia, especially in Banyuwangi Regency which has a large amount of liquid waste pollution and can have an impact on human health. Environment around the industry because whey cheese contains relatively high organic content so that it is easy to decompose and rot. The discoloration characterizes whey rot from greenish yellow to dark brown and rotten. This stench will interfere with human breathing, and if it flows into the river it will be a source of disease for humans. Another supportive reason is that Acetobacter xylinum is obtained commercially and obtained naturally from pineapples.

Research that uses nata de coco as a control in hopes of getting better quality nata de coco than nata de 
coco in terms of taste, chewiness, texture, color, fiber content, protein, and from an economic perspective. So that it can produce nata de whey products that are ready to sell.

\section{MATERIALS AND METHODS}

This research was conducted in the Laboratory of The Study Program of Technology Processing Ternak Livestock Products Polytechnic of Banyuwangi State and started from the observation or observation stage, collecting raw materials in the CV. Margo Utomo, Kalibaru Village, Kalibaru District, Banyuwangi Regency.

The data was generated from this study and analyzed using two randomized factorial design (RAK) experiments; namely, the first factor is the difference in raw materials, namely coconut water, whey, and the second-factor fermentation three replays.

According to the concentration used, the manufacture of nata de whey and nata de coco required the main ingredients of whey cheese and coconut water. Each heavy treatment of the sample $\pm 1,000 \mathrm{ml}$ is initially with whey filtration, sucrose as much as $5 \%$, and added $10 \%$ glacial acetic acid until the whey's pH reaches $\mathrm{pH} 4$. Whey is then pasteurized at $62-65^{\circ} \mathrm{C}$ for 30 minutes. This pasteurization aims to kill pathogenic and decaying microorganisms. Whey is then poured into a rectangular baking sheet and silenced until the temperature drops to $28-32^{\circ} \mathrm{C}$. The next stage is the inoculation of Acetobacter culture sp. from pineapple as much as $15 \%(150 \mathrm{ml})$ then tightly covered with a straining cloth. The strainer fabric has a relaxing structure for Acetobacter sp. can react with the oxygen needed; addition, Acetobacter sp. is anaerobic bacteria. Incubation has been carried out at room temperature for 8,11 , and 14 days until nata is formed. And then, nata cut into small pieces. Deacidification (acid removal) is carried out by immersion using aquades overnight and boiling.

\section{RESULTS AND DISCUSSIONS}

This study's physicochemical qualities include redeeming, thickness, fiber content, fat content, protein content, and $\mathrm{C}$ vitamin levels. The old treatment of fermentation and the source of different raw materials have a significant effect (Pvalue $<0.01$ ) and have interactions with chemical quality testing, namely proteins, crude fiber, crude fats, and vitamins. While in the physical quality testing of the treatment of long fermentation and raw material sources have no interaction, but judging by the average of the old treatment fermentation has an authentic influence (Pvalue<0.01) physical quality and the treatment of different raw material sources also has a real effect (Pvalue $<0.01$ ) physical quality. Table 1 is the ANOVA data of all parameters (physicochemical quality) tested on nata de whey.

Table-1: The Results of Nata De Whey's Physicochemical Quality

\begin{tabular}{|c|c|c|c|c|}
\hline \multirow[t]{2}{*}{ Parameter } & \multirow[t]{2}{*}{ Treatment } & \multicolumn{2}{|c|}{ Fermentation Time } & \multirow[t]{2}{*}{ Mean } \\
\hline & & 11 days & 14 days & \\
\hline \multirow{2}{*}{$\begin{array}{l}\text { Crude } \\
(\mathrm{gr})\end{array}$} & $\mathrm{P} 0$ & $0.42 \pm 0.01^{\mathrm{D}}$ & $0,45 \pm 0,01^{\mathrm{C}}$ & \\
\hline & $\mathrm{P} 1$ & $1,28 \pm 0,01^{\mathrm{A}}$ & $1,14 \pm 0,01^{\mathrm{B}}$ & \\
\hline \multirow[t]{2}{*}{ Crude fiber (gr) } & $\mathrm{P} 0$ & $0,44 \pm 0,01^{\mathrm{C}}$ & $0,62 \pm 0,01^{\mathrm{A}}$ & \\
\hline & $\mathrm{P} 1$ & $0.31 \pm 0.01^{\mathrm{D}}$ & $0,47 \pm 0,01^{\mathrm{B}}$ & \\
\hline \multirow[t]{2}{*}{ Crude Fat (gr) } & $\mathrm{P} 0$ & $0,11 \pm 0,05^{\mathrm{C}}$ & $0.10 \pm 0.05^{\mathrm{D}}$ & \\
\hline & P1 & $0,24 \pm 0,01^{\mathrm{A}}$ & $0,13 \pm 0,05 \mathrm{~B}$ & \\
\hline \multirow{2}{*}{$\begin{array}{ll}\text { Vitamin } & C \\
(\mathrm{mg} / 100 \mathrm{~g}) & \end{array}$} & $\mathrm{P} 0$ & $0,087 \pm 0,001^{\mathrm{B}}$ & $0.0013 \pm 0.0005^{\mathrm{D}}$ & \\
\hline & $\mathrm{P} 1$ & $0,102 \pm 0,005^{\mathrm{A}}$ & $0,025 \pm 0,005^{\mathrm{C}}$ & \\
\hline \multirow{3}{*}{$\begin{array}{l}\text { Cellulose } \\
\text { Thickness (mm) }\end{array}$} & $\mathrm{P} 0$ & $16,65 \pm 0.62$ & $22,29 \pm 2,38$ & $19,47 \pm 3,46^{\mathrm{A}}$ \\
\hline & P1 & $6,60 \pm 0,83$ & $14,86 \pm 0,93$ & $10,73 \pm 4,58^{\mathrm{B}}$ \\
\hline & Mean & $11,62 \pm 5,54^{\mathrm{B}}$ & $18,57 \pm 4,38^{\mathrm{A}}$ & \\
\hline \multirow[t]{3}{*}{ Redeem (\%) } & $\mathrm{P} 0$ & $34,4 \pm 3,80$ & $58,63 \pm 2,38$ & $46,51 \pm 13,56^{\mathrm{A}}$ \\
\hline & $\mathrm{P} 1$ & $15,58 \pm 1,81$ & $36,58 \pm 0,77$ & $26,08 \pm 11,56^{\mathrm{B}}$ \\
\hline & Mean & $24,99 \pm 10,57^{\mathrm{B}}$ & $47,60 \pm 12,18^{\mathrm{A}}$ & \\
\hline
\end{tabular}

Description: Different notations on the same line show very real different $1 \%$ test levels. $\mathrm{P}_{0}=$ Coconut water + Acetobacter xylinum commercial $15 \%, \mathrm{P}_{1}=$ whey + Acetobacter xylinum $15 \%$.

\section{Crude Protein}

The ANOVA results in Table 1 showed that crude proteins' content in the treatment of different stater sources and extra fermentation length is genuine (Pvalue $<0.01$ ). Both treatments have authentic interactions. The treatment of P1 (whey cheese) is natural has a higher protein content, which is $1.28 \mathrm{gr}$ for fermentation time of 11 days and $1.14 \mathrm{gr}$ for fermentation time of 14 days, compared to P0 (coconut water). This difference is due to the raw materials used in $\mathrm{P} 1$, namely whey cheese, with protein content such as $\beta$-Lactoglobulin $12 \%, \quad \beta$-Lactalbumin $4 \%$, immunoglobulins $3 \%$, serum albumin $1 \%$, and proteins produced from Acetobacter xylinum [4]. While nata 
made from the coconut water source raw only has a crude protein content of $0.42 \mathrm{gr}$ for fermentation time of 11 days and 0.45 gr for 14 days. This is because there is no protein content in coconut water, resulting from fermentation with Acetobacter xylinum.

\section{Crude Fiber}

The results of the analysis in Table 1 showed that the content of crude fibers in the treatment of different stater sources and other fermentation times is genuine (Pvalue $<0.01$ ). Both treatments have authentic interactions. P0 treatment (coconut water) with a fermentation time of 14 days is natural has the highest rain content of 0.62 gr. Successively followed by the content of Fiber in P1 (whey) with a 14 days fermentation time, which is $0.47 \mathrm{gr}, \mathrm{P} 0$ (coconut water) with a fermentation time of 11 days, which is $0.44 \mathrm{gr}$, and the last P1 (whey) with a fermentation time of 11 days which is 0.31 gr. The data shows that the amount of crude fiber in nata is influenced by the fermentation time and the source of raw materials used for the manufacture of nata. The longer fermentation, the higher the level of crude fiber produced due to the optimum growth of Acetobacter xylinum. The source of nitrogen and the length of fermentation can affect the high change of Acetobacter xylinum [5]. Another reason is that the long fermentation of Acetobacter xylinum will undergo an exponential phase. All Acetobacter xylinum will also secrete as many extracellular enzymes polymers to compose glucose polymers into cellulose so that more matric nata is produced in this phase. Coconut water has a content of sodium, potassium, fiber, and carbohydrates. These substances are substances needed by Acetobacter xylinum in their growth. Acetobacter xylinum requires a source of nutrients $\mathrm{C}, \mathrm{H}$, and $\mathrm{N}$ and some minerals to grow and convert those nutrients into nata (cellulose fibers) [6].

\section{Crude Fat}

The results of the ANOVA analysis in Table 1 showed that the content of crude Fat in the treatment of different stater sources and extra fermentation length is genuine (Pvalue $<0.01$ ). Both treatments have authentic interactions. The very real P1 (whey cheese) treatment has a higher protein content of $0.24 \mathrm{gr}$ for fermentation time of 11 days and 0.13 gr for fermentation time of 14 days, compared to P0 (coconut water). This difference is due to the raw materials used in P1, namely whey cheese has a fat content of $0.3 \mathrm{gr}$ and fat content of coconut water of 0.2 gr [7]. The fermentation process using Acetobacter xylinum bacteria can lower each raw material's fat content because the Fat contained in the media is used for metabolism in the formation of nata. Fat in reduced media will affect the fat content in nata because the Fat contained in nata is Fat trapped by the matrix of nata. The fat content in fat content is utilized by Acetobacter xylinum to form nata fibers so that the more content nata then the fat content is reduced.

\section{Vitamin C}

The results of the ANOVA analysis in Table 1 showed that the content of vitamin $\mathrm{C}$ in the treatment of different sources of stater and extra fermentation length is genuine (Pvalue<0.01). Both treatments have authentic interactions. P1 treatment (whey cheese) is natural has a higher vitamin $\mathrm{C}$ content of 0.102 $\mathrm{mg} / 100 \mathrm{~g}$ for fermentation time of 11 days, followed by treatment P0 (coconut water), which is $0.087 \mathrm{mg} / 100 \mathrm{~g}$ for fermentation time 11 day, then P1 treatment (whey cheese), i.e., $0.025 \mathrm{mg} / 100 \mathrm{~g}$ for fermentation time of 14 days and treatment P0 (coconut water), i.e., $0.0013 \mathrm{mg} / 100 \mathrm{~g}$ for fermentation time of 14 days. This data showed that the longer the fermentation time can decrease the content of vitamin $\mathrm{C}$. This is due to vitamin C's oxidation into L-dehydroascorbic acid and then into L-diketogulonicacid [8]. The resulting vitamin $\mathrm{C}$ stored at $29^{\circ} \mathrm{C}$ would experience oxidation during storage [9].

\section{Cellulose Thickness}

The results of the ANOVA analysis in Table 1 showed that the thickness of cellulose in the treatment of different stater sources and fermentation length is not other (Pvalue>0.01), and there is no interaction between the two treatments. However, table 1 showed that the size of fermentation has a very noticeable effect (Pvalue >0.01) on cellulose thickness; a fermentation time of 14 days results in a higher cellulose thickness of $18.57 \mathrm{~mm}$ compared to the fermentation time of 11 days, which is $11.62 \mathrm{~mm}$. During the fermentation process, the thickness of nata de whey has increased. The longer the fermentation time, the thicker the nata is produced. It can be concluded that the length of fermentation nata de whey affects the thickness of the nata formed. Different sources of raw materials also have an authentic influence (Pvalue $>0.01$ ) on cellulose thickness; P0 (coconut water) has a higher cellulose thickness of $19.47 \mathrm{~mm}$ compared to P1 (whey cheese) of $10.73 \mathrm{~mm}$. More nutrients are available, and more cellulose braiding is produced as a secondary metabolite product [11]. Cellulose braiding is said to continue to bind to form a sturdy and compact bond. Biomass nata comes from the growth of Acetobacter xylinum during the fermentation process in media containing sugar and acid. Coconut water has the nutrient content needed by developing Acetobacter xylinum, such as Sodium, Potassium, and carbon sources.

\section{Redeem}

The results of the ANOVA analysis in Table 1 show that the redeem. The treatment of different stater sources and fermentation length is not other (Pvalue>0.01), and there is no interaction between the two treatments. However, Table 1 shows that the size of fermentation exerts an authentic influence (Pvalue $>0.01$ ) on the redeem. The fermentation time of 14 days produces a higher save, $47.60 \%$, compared to 
11 days, $24.99 \%$. It can be concluded that the length of fermentation nata de whey affects the reindeer that are formed. Different sources of raw materials also have an authentic influence (Pvalue>0.01) on the reindeer; P0 (coconut water) has a higher redeem of $46.51 \%$ compared to P1 (whey cheese) of $26.08 \%$. Proses nata formation occurs through the activity of Acetobacter xylinum bacteria that use glucose as a source of carbon in its metabolic processes. This metabolic process will be combined with fatty acids that will form a precursor on the cell membrane. This precursor is then secreted in excretion, and an enzyme was polymerizing glucose into cellulose outside the cell [10]. The length of fermentation of nata causes the bacteria Acetobacter xylinum to work on the treatment of different amounts of nutrients that meet its needs. In conditions where the amount of nutrients meets the needs of cellulose that is formed in large quantities. The longer the fermentation time, the heavier the nata form, so the nata redeem also increases. Different fermentation times are produced, and cellulose levels are different, so nata de whey gets more massive, and the reindeer increases. Redeem are influenced by substrate variations, material composition, environmental content Acetobacter xylinum's ability to produce cellulose.

\section{CONCLUSIONS}

The results of the Physicochemical analysis showed that the chemical quality (crude Protein, Crude Fiber, crude Fat, and $\mathrm{C}$ vitamins content) in the treatment of different stater sources and other fermentation times was very significant (Pvalue<0.01) and have interactions between the two treatments. But on physical quality (redeem and cellulose thickness) on the treatment of different stater sources and fermentation length is not significant (Pvalue>0.01).

\section{ACKNOWLEDGEMENTS}

The acknowledgments are addressed to the Banyuwangi State Polytechnic, which has provided this research grant through the 2020 PNBP Fund of Research Master Plan Program.

\section{REFERENCES}

1. Khusna A, Prastujati A, Setiadevi S, Hilmi M. Effect of starter sources and old fermentation on making nata de whey towards chemical quality. InE3S Web of Conferences 2020 (Vol. 142, p. 04001). EDP Sciences.

2. Usmiati S, Bakar A. Teknologi pengolahan susu. Balai Besar Penelitian dan Pengembangan Pascapanen Pertanian Press, Bogor. 2009.

3. Rubijanto JP, Kiswanto A, Subri M. Pembuatan Alat Uji Kekasaran Permukaan (Surface Roughness Test). In prosiding seminar nasional \& internasional. 2004 (Vol. 1, No. 2).

4. Keri Marshall ND. Therapeutic applications of whey protein. Alternative medicine review. 2004;9(2):136-56.

5. Bethan MS, Fadillah HN. Pembuatan Nata De Pina Dari Limbah Kulit Nanas (Ananas Comusus L. Merr) Dengan Proses Fermentai Menggunakan Bakteri Acetobacter Xylinum $=$ Making Nata De Pina from Pineapple Skin Waste (Ananas Comusus L. Merr) with Fermentation Process Using Bacteria Acetobacter Xylinum (Doctoral dissertation, Institut Teknologi Sepuluh Nopember).

6. Hamad A, Kristiono K. Pengaruh Penambahan Sumber Nitrogen Terhadap Hasil Fermentasi Nata de Coco. Jurnal ilmiah momentum. 2013;9(1).

7. Al Awwaly KU, Puspadewi A, Radiati LE. The Utilization of Different Starter and Incubation Time on Texture, Fat Content and Organoleptic Properties of Nata de Milko. Jurnal Ilmu dan Teknologi Hasil Ternak (JITEK). 2011;6(2):26-35.

8. Fellows PJ. Food processing technology: principles and practice. Elsevier; 2009 Jun 22.

9. Rachmawati RA, DEFIANI MR, Suriani NL. Pengaruh suhu dan lama penyimpanan terhadap kandungan vitamin $\mathrm{C}$ pada cabai rawit putih (Capsicum frustescens). Jurnal Biologi Udayana. 2009;13(2).

10. Budiarti RS. Pengaruh konsentrasi starter Acetobacter xylinum terhadap ketebalan dan rendemen selulosa nata de soya. Biospecies. 2008;1(1).

11. Ross P, Weinhouse H, Aloni Y, Michaeli D, Weinberger-Ohana $\mathrm{P}$, Mayer $\mathrm{R}$, Braun $\mathrm{S}$, De Vroom E, Van der Marel GA, Van Boom JH, Benziman M. Regulation of cellulose synthesis in Acetobacter xylinum by cyclic diguanylic acid. Nature. 1987 Jan;325(6101):279-81. 